\title{
発語失行の責任病巣
}

\begin{abstract}
鈴木 匡子
要 約：発語失行の責任病巣については長年議論されてきたが，どの部位が最も重要かに関 しては異論も多い。これまで報告された左半球病巣による純粋発語失行例 21 例をまとめると, 1 例を除き全例で中心前回下部が病巣に含まれていた。一方，失語症で発語失行の要素を含む 症例の検討では島前部を重視する報告が出された。われわれは，言語優位半球病巣をもつ症例 において構音を含む言語機能および行為について検討した。また，脳腫瘍例においては皮質電 気刺激による術中言語マッピングを施行した。その結果, 発語失行の責任病巣としては言語優 位半球中心前回下部が最も重要で，島前部は必須の領域ではないことが示された。術中マッピ ングでは, 中心前回下部は口舌の運動野や negative motor area と同定される例が多かった。 以上より, 言語優位半球中心前回下部は高次の運動コントロールに密接に関係しつつ, “言語野” として働いていると推定された。
\end{abstract}

索引用語：発語失行, 失構音, 中心前回, 皮質電気刺激, 術中マッピング

\section{Neuronal Bases of "Apraxia of Speech"}

\author{
Kyoko Suzuki
}

\begin{abstract}
Apraxia of speech (AOS) has been reported to be closely related to frontal lesions in the language dominant hemisphere. However, the exact location of the lesion that causes AOS remains to be determined. We reviewed reported cases of pure AOS in which lesions were clearly demonstrated by MRI, CT or autopsy studies. Twenty-one cases had unilateral lesions in the left cerebral hemisphere, and all except one demonstrated lesions in the inferior part of the left precentral gyrus. In contrast, another study examining aphasic patients with AOS as one element of aphasic symptoms had a left insular lesion in common.

We examined patients with left frontal and insular lesions to clarify the region crucial to causing AOS. All patients with AOS had lesions in the left precentral gyrus, while patients without AOS demonstrated lesions including the insular cortex but not the precentral gyrus. Language mapping using electric cortical stimulation during operation revealed that stimulation to the inferior part of the left precentral gyrus caused speech arrest or delayed responses. These impairments were not language specific but were related to the tongue motor area or negative motor areas. These findings suggest that the left precentral gyrus may strategically act as a node to control complex orolingual movements including speech.
\end{abstract}

東北大学大学院医学系研究科高次機能障害学 : $=980-8575$ 仙台市青葉区星陵町 2-1

Division of Neuropsychology, Department of Disability Medicine, Tohoku University Graduate School of Medicine : 2-1 Seiryo-machi, Aobaku, Sendai 980-8575 2004 年 1 月 21 日受理 
Key words : anarthria, precentral gyrus, insula, cortical stimulation, intraoperative mapping

\section{はじめに}

発語失行の責任病巣はどこかという問いは古くて新 しい問題である。近年の神経画像法の普及により病巣 の詳細な検討が可能となったものの, 発語失行の出現 に最も重要な部位については必ずしも意見が一致して いない.これには発語失行の定義，発語失行の出現時 期, 病巣の同定方法などが研究ごとに異なっているこ とも関連している。そこで本稿では発語失行報告例の 病巣について再検討するとともに，自験例において症 状と病巣の関係を検討する。 また, 術中皮質電気刺激 による言語マッピングにより，発語に関連する領野を 明らかにする，なお，本稿では便宜上，失構音と同義 として発語失行を用いるが，特に失行的側面を強調す る立場ではない。

\section{発語失行純粋例}

発語失行の純粋例は数少ない。そのうち, 以下の条 件をもつ報告例をまとめた；1）発語失行以外の明ら かな言語症状がない，2)病巣を剖検， CT, MRI のい
ずれかで正確に同定できる，3)左半球病巣をもつ(右 半球に病巣があり，言語の側性化が通常と異なること が示唆される症例があるため).これらの条件に合致し た 21 症例を表 1 に示す ${ }^{1-18)}$. 表から明らかなように Denny-Brown ${ }^{2)}$ の報告を除き，全例で中心前回下部が 病巣に含まれていた。島病変は 6 例で, 中・下前頭回 後部病変は 6 例で認められた。

また，中心前回下部に限局病巣をもち，皮質性構音 障害として報告される例がある ${ }^{19)}$. 構音障害以外の症 状としては，舌の動きの拙劣さを伴う．明らかな言語 症状，口舌顔面失行はないとされるが，詳細な検討は なされていない. 発語失行との臨床的差異として, 発 症時に無言状態にならなかったことと舌運動の拙劣さ を挙げているが，構音障害の質的特徵は失構音（発語 失行）に類似するだろうとしている．利き手の記載は ないが，6 例中 5 例が左中心前回下部病巣で言語優位 半球側に偏って抢り, 発語失行に連続する症候と考元 られる。

表 1 左半球病巣による発語失行純粋例の病巣部位

\begin{tabular}{|c|c|c|c|c|c|c|c|c|}
\hline \multirow{2}{*}{ 著者 } & \multirow[t]{2}{*}{ 年 } & \multirow[t]{2}{*}{ 病因 } & \multirow{2}{*}{$\begin{array}{c}\text { 病巣の } \\
\text { 確認 }\end{array}$} & \multicolumn{2}{|c|}{ 前頭回 } & \multicolumn{2}{|c|}{$\begin{array}{c}\text { 病巣 } \\
\text { 中心前回 }\end{array}$} & \multirow[t]{2}{*}{ 島 } \\
\hline & & & & 上 中 & 下 & 上部 & 下部 & \\
\hline Ladame $^{1)}$ & 1908 & 脳梗塞 & 剖検 & + & + & & + & \\
\hline Denny-Brown ${ }^{2)}$ & 1965 & 脳梗塞 & 剖検 & + & + & & & \\
\hline Lecours $^{3)}$ & 1976 & 脳梗塞 & 剖検 & + & & & + & + \\
\hline Tonkonogy ${ }^{4)}$ & 1981 & 脳梗塞 & 剖検 & & + & & + & \\
\hline \multirow[t]{2}{*}{ Schiff ${ }^{5)}$} & 1983 & 脳梗塞 & $\mathrm{CT}$ & & & & + & + \\
\hline & & 脳梗塞 & $\mathrm{CT}$ & & & & + & \\
\hline 森6) & 1983 & 脳出血 & $\mathrm{CT}$ & & & & + & \\
\hline Sugishita ${ }^{7)}$ & 1987 & 脳梗塞 & MRI & & & & + & + \\
\hline \multirow[t]{2}{*}{ 遠藤8) } & 1988 & 脳梗塞 & $\mathrm{CT}$ & & & & + & \\
\hline & & 脳出血 & $\mathrm{CT}$ & & & & + & \\
\hline Mori ${ }^{9)}$ & 1989 & 脳腫瘍 & 剖検 & & & & + & \\
\hline 長谷川10) & 1990 & 脳梗塞 & $\mathrm{CT}$ & & & & + & + \\
\hline 越部 ${ }^{11)}$ & 1991 & 脳梗塞 & $\mathrm{CT}$ & + & & & + & \\
\hline 吉野12) & 1993 & 脳出血 & MRI & & & & + & \\
\hline 會澤13) & 1994 & 脳梗塞 & MRI & & & & + & \\
\hline Fukui $^{14)}$ & 1996 & Pick 病 & 剖検 & & + & & + & + \\
\hline \multirow[t]{2}{*}{ 齊籐15) } & 1997 & 脳梗塞 & MRI & & & & + & \\
\hline & & 脳梗塞 & MRI & & & & + & \\
\hline Sakurai ${ }^{16)}$ & 1998 & Pick 病 & 剖検 & & & & + & + \\
\hline 田淵17) & 2000 & 脳梗塞 & MRI & & & & + & \\
\hline Fox $^{18)}$ & 2001 & 脳梗塞 & $\mathrm{CT}$ & & & & + & \\
\hline
\end{tabular}




\section{失語症の部分症状としての発語失行}

Dronkers は, 失語症例で発語失行の要素を含む症 例と発語失行の要素のない症例の病巣部位をそれぞれ 重ね合わせた ${ }^{20)}$. その結果, 発語失行のある症例全例で 島前部が病巣に含まれ, 発語失行のない症例では島前 部に病巣がなかった。この二重解離により島前部が発 語失行の出現に必須な部位と結論づけられたが，いく つか問題もある。まず，この研究では病巣の同定に MRI でなくCT を用いた症例も含まれるため, 病巣範 囲の決定と重ね合わせの方法が十分に正確でない可能 性がある。症状に関しては, 失語症の部分症状として の発語失行を捉えているため, 発症機序が 1 つとは限 らない。また, 発症機序の解明には発症症状や回復過 程が参考になるが，対象は発症後 1 年以降の発語失行 の有無で分類されているため検討できない.

\section{健常人の発語に関する神経機能画像研究}

単語復唱課題での血流変化を PET を用いて検討し た研究では, 左島前部の血流増加が認められたが，左 右の中心前後回でも血流は増加していた ${ }^{21}$. また, 復唱 課題から単語聴取課題を直接サブトラクションした場 合は, 左島の血流増加は見られなかった。機能的 MRI を用いた研究で, 語音を一定のペースで繰り返し発話 する課題では，多音節無意味綴りを発話するときのみ 左中心前後回下部に限局した血流増加が見られた ${ }^{22)}$. 単音節の繰り返しや舌の左右運動では両側に同程度の 賦活が，単語の繰り返しの場合は両側ながら左優位の 賦活が中心前後回に観察された。このように，発話過 程を含む課題でもその内容によって当然賦活部位は異 なり, 高次の構音に関する部位のみを抽出するのは容 易でない.

\section{自験例による検討}

われわれは発語失行の発現に重要なのは中心前回下 部か島前部かを検討するために以下の観察を行った。 対象は言語優位半球前頭葉病巣をもつ患者 18 名で, 病 巣部位により以下の 4 群に分けられた； I . 中心前回 群 3 名（中心前回下部にほぼ限局し，島や下前頭回を 含まない), II. 中心前回・島群 6 名, III. 島群 6 名 (中 心前回下部を含まず，島と下前頭回などを含む)，IV. 中前頭回群 2 名. 構音を含む言語機能および行為につ いて, 脳腫腸例では術前・術後, 脳梗塞例は慢性期に 検討した。

結果として, 中心前回を含む I, II群では全例に発
語失行を認め, 中心前回病変のないIII，IV群では発語 失行は認められなかった。中心前回病巣では, シルビ ウス裂に接する最下部は必ずしも含まれず，中前頭回 から下前頭回後方の中心前回が病巣の中心だった．発 語失行例で口舌顔面失行を伴ったのは一部で，必ずし も口舌顔面失行が合併しないことが明らかになった。 また, 中心前回群で一過性の書字障害（かな優位）お よび語列挙の低下が見られた。

\section{術中言語マッピングによる検討}

脳腫瘍例 7 名においては皮質電気刺激による術中機 能マッピングを施行した。手術中に覚醒下で皮質を直 接電気刺激することにより，その部位の言語機能を検 討した．刺激の強さは後発射の生じない強さとし，時 間は 2-3 秒であった。まず，一次感覚野と一次運動野 を同定した．その後，カウンティング課題を行いなが ら，手術予定部位を中心に皮質を電気刺激し，発話の 停止，遅延，誤りなどが認められる部位を同定した。 異常が認められた部位では舌や手の運動を行いながら negative motor area か否かを確認した。ささらに，コ ンピューターの画面で線画を見せて呼称課題を行い, 皮質電気刺激により異常の生じる部位を同定した。

術中マッピングでは，中心前回下部で発語停止，発 語遅延などが見られたが, 口舌の運動そのものに障害 がある場合がほとんどであった。すなわち，口舌の運 動野や negative motor area と同定される例が多く, 発語に特異的とはいえなかった。 下前頭回後部刺激で は呼称課題で異常の見られる場合があり, 喚語困難と 考えられた。

\section{ま と め}

以上より, 発語失行の責任病巣としては言語優位半 球中心前回下部が最も重要であると考えられる.中心 前回下部は高次の運動コントロールに密接に関係しつ つ，“言語野”として働いていると推定された。

\section{文献}

1) Ladame, P.-L. and von Monakow, C.: Observation d' aphemie pure (Anarthrie corticale). Encéphale, 3 : 193-228, 1908

2) Denny-Brown, D.: Physiological aspects of disturbances of speech. Aust J Exp Biol Med Sci, 43 : 455-474, 1965.

3) Lecours, A.R. and Lhermitte, F.: The "pure form" of the phonetic disintegration syndrome (pure anarthria); Anatomo-clinical report of a historical case. Brain Lang, $3: 88-113,1976$.

4) Tonkonogy, J. and Goodglass H.: Language function, 
foot of the third frontal gyrus, and Rolandic operculum. Arch Neurol, 38: 486-890, 1981.

5) Schiff, H.B., Alexander, M.P., Naeser, M.A., et al: Aphemia. Clinical-anatomic correlations. Arch Neurol, 40 : 720-727, 1983.

6）森 悦朗, 山鳥 重, 須山 徹, 他: 左中心前回弁蓋部と 失語症. 失語症研究, $3: 450-458,1983$.

7) Sugishita, M., Konnno, K., Kabe S., et al: Electropalatographic analysis of apraxia of speech in a left hander and in a right hander. Brain, 110:1393-1417, 1987.

8）遠藤邦彦, 牧下英夫, 谷崎義生, 他：構音失行の純粋例で 認められた構音器官の非言語的運動の障害について. 失語 症研究, 8：224-236, 1988.

9) Mori, E., Yamadori, A. and Masaru, F.: Left precentral gyrus and Broca's aphasia: A clinicopathologic study. Neurology, $39:$ 51-54, 1989.

10) Hasegawa, O., Suzuki, J. and Kyuma, Y.: A case of anarthria accompanied by bucco-facial apraxia with slight involvement of Kana writing. Shinkeinaika, 32 : 75-78, 1990 (in Japanese).

11）越部裕子, 宇野 彰, 紺野加奈江, 他：純粋語啞例におけ る非構音時の高次口腔顔面動作と構音の関係について一口 腔顔面動作訓練と構音訓練一. 失語症研究, $11: 262-270$, 1991.

12）吉野眞理子, 河村 満：純粋発語失行症例における発話の 経時的検討. 聴脳言語学研究, $10 ： 110-119,1993$.

13）會澤房子, 相馬芳明, 中島 孝, 他：モーラ指折り法によ って顕著な発話改善を呈した aphemia の 1 例. 失語症研 究, $14: 258-264,1994$.

14) Fukui, T., Sugita, K., Kawamura, M., et al: Primary progressive apraxia in Pick's disease: A clinicopath- ologic study. Neurology, $47:$ 467-473, 1996.

15）齊籐祐子, 喜多也寸志, 板東充秋, 他：左中心前回損傷に おける神経心理学的分析一特に書字障害について一. 臨床 神経学, 37 :487-491, 1997.

16) Sakurai, Y., Murayama, S., Fukusako, Y., et al: Progressive aphemia in a patient with Pick's disease: a neruopsychological and anatomic study. J Neurol Sci, $159: 156$ $-161,1998$.

17）田淵実治郎, 小田島加奈子, 鈴木匡子, 他：左中心回病変 と純粋語啞. 臨床神経学, 40：464-470, 2000.

18) Fox, R.J., Kasner, S.E., Chatterjee, A., et al: Aphemia: an isolated disorder of articulation. Clin Neurol Neurosurg, $103: 123-126,2001$.

19) Kim, J.S., Kwon, S.U. and Lee, T.G.: Pure dysarthria due to small cortical stroke. Neurology, $60: 1178-1180$, 2003.

20) Dronkers, N.F.: A new region for coordinating speech articulation. Nature, 384:159-161, 1996.

21) Wise, R.J.S., Greene, J., Bühel, C., et al: Brain regions involved in articulation. Lancet, 353 : 1057-1061, 1999.

22) Riecker, A., Ackermann, H., Wildgruber, D., et al: Articulatory/phonetic sequencing at the level of the anterior perisylvian cortex: A functional magnetic resonance imaging (fMRI) study. Brain Lang, 75 : 259-276, 2000.

別刷請求先：干 980-8575 仙台市青葉区星陵町 2-1 東北大学大学院医学系研究科 高次機能障害学 鈴木匡子 